\title{
Ban on Plastic Bags Usage: Consumer Perception of Single-Use Plastic Bags in Traditional Market
}

\author{
Parida Angriani ${ }^{1 *}$ Muhammad Muhaimin $^{1}$ Karunia Puji Hastuti $^{1}$ Sidharta $_{\text {Adyatma }}{ }^{1}$ \\ Aswin Nur Saputra ${ }^{1}$
}

${ }^{1}$ Geography Education Department, Faculty of Teacher Training and Education, Lambung Mangkurat University, Banjarmasin, Indonesia

${ }^{*}$ Corresponding author. Email: parida.angriani@ulm.ac.id

\begin{abstract}
The policy of prohibiting the use of disposable plastic bags in force in Indonesia is an attempt by the government to reduce the amount of plastic waste. However, the effectiveness of the policy is still questionable, because it is only applied in modern retail stores, while the biggest contributor to plastic bag waste is in the traditional market. This study aims to determine consumer perceptions of government policy regarding the prohibition of the use of disposable plastic bags in traditional markets and the amount of their willingness to pay (willingness to pay) for each plastic bag used. Data was collected using a survey questionnaire to traditional market consumers. The results of the study revealed that the majority of consumers agreed if the policy was applied in traditional markets, but with a note of its gradual application. They also agreed with the implementation of paid plastic bags. Their reasoning is based on the perception that the policy can increase public awareness and concern to reduce the use of disposable plastic bags. The average value of consumers' willingness to pay for a plastic bag varies and can still be reached, so consumers are still willing to pay more. So, if you want to reduce the use of plastic bags in the community, the price of plastic bags must be even more expensive or look for alternatives to plastic bags, such as the use of shopping baskets/bags or the use of environmentally friendly plastic bags.
\end{abstract}

Keywords: Single-use plastic bags, willingness to pay, traditional market.

\section{INTRODUCTION}

Plastic waste is one of the global problems facing the world today, including Indonesia. As the population increases, the volume of waste generation generated from human activities also increases. Every year, the volume of waste always increases with the increasing pattern of consumerism [1-3]. The Ministry of Environment and Forestry (KLHK) recorded that in 2018 the amount of waste produced nationally reached 175,000 tons/day or 64 million tons/year, if it assumes that the waste produced per person/day is $0.7 \mathrm{~kg}$. This number continues to increase in 2019 which is estimated to be around 66-67 tons of waste [4].

The amount of waste generation generated requires serious handling in its management. The Law of the Republic of Indonesia concerning Waste Management issued in 2008 and the Government of the Republic of Indonesia Regulation on Management of Household Waste and Trash of Similar Household Waste issued in 2012 mandated the need for a fundamental paradigm shift in waste management, namely from the transport collection paradigm waste, into processing that relies on waste reduction and waste handling. Waste management can be done with a comprehensive approach [5-8].

One way to reduce waste, especially plastic waste is to reduce the habit of using disposable plastic bags.
Familiarize the public in reducing the use of disposable plastic bags as stipulated in the Banjarmasin City Mayor Regulation on Reducing the Use of Plastic Bags. This regulation came into force on June 1, 2016, and starting from that date all modern retail stores are prohibited from providing plastic bags. This policy aims to minimize volume, distribution and use wisely and gradually reduce dependence on plastic bags that are not environmentally friendly but, in the mayor's regulation, the goal of reducing the use of disposable plastic bags is only targeting middle and upper business actors, such as retail stores, modern stores, and supermarkets/minimarkets so that these businesses no longer provide plastic bags and people who shop at retail stores must bring their shopping bags or they have to buy cloth bags provided by the store.

The policy issued by the Mayor of Banjarmasin is the first step in efforts to reduce plastic waste in the environment, but the basic problem is the use of plastic bags in traditional markets because there are no regulations that govern this. The traditional market as one of the shopping centers is the largest contributor to plastic bags [9]. Seeing the reality, Banjarmasin City Government is making a program related to reducing the use of plastic bags (plastic bag diet program) in traditional markets, so that the reduction of plastic waste is more maximized [10]. 
The program that has been implemented by the Banjarmasin City Government in mid-2019 is the distribution of 4000 baskets (shopping bags made from purun woven) in the Teluk Dalam Market, Central Banjarmasin District to buyers and traders. The socialization was also carried out at Cemara Market, North Banjarmasin District; Pandu Market, East Banjarmasin District; Pekauman Market, South Banjarmasin District; and Kalindo Market, West Banjarmasin District. Based on the socialization carried out, buyers who shop at traditional markets are expected to bring their shopping bags (bags), and if not they must pay the seller each plastic bag used to wrap shopping items.

Public awareness of the importance of reducing plastic waste is the goal of implementing the policy. Thus, people's perceptions of the prohibition of using plastic bags, especially in traditional markets, need to be studied in more depth. If they have to pay for every plastic bag used when shopping, then the public's ability to pay the price of a plastic bag when shopping is also important. The purpose of this study is to find out consumers' perceptions of government policies regarding the prohibition of the use of disposable plastic bags in traditional markets and the amount of their willingness to pay for plastic bags when they are paid. This research is an input to the government regarding the policy of reducing the use of plastic bags in traditional markets.

\section{THEORETICAL FRAMEWORK}

Public policy related to waste management is one of the government's efforts to reduce the negative effects of waste. Policies can be applied to start from the waste generated, the process of collection, transportation, to final disposal [11]. This policy can be applied to various types of waste.

Especially for plastic bag waste, in various developed countries the use of plastic shopping bags in stores and supermarkets is starting to be limited and replaced with cloth bags [12]. In the United States, stores and supermarkets that still provide plastic bags are liable to a $\$$ 100 fine for the first offense, and a $\$ 200$ fine for subsequent violations, if still violated, a \$ 500 fine [13]. In Australia, shops sell fabric shopping bags at very cheap prices but can be used many times [14]. While in England, some supermarkets give special discounts worth 1-4 pounds for buyers who bring their bags from home [15].

In Indonesia various efforts have been made by the government related to reducing the use of disposable plastic bags in the community, such as (1) restrictions on the use of shopping plastic bags, both in modern retailers or traditional markets (green mall or green retailer programs); (2) optimization of existing plastic waste recycling by the local government, the informal sector or the community; (3) partnership of the government and producers of goods and/or goods with plastic packaging; and (4) socialization of plastic waste sorting and recycling programs through the Waste Bank Program [16].

The policy of reducing the use of disposable plastic bags, in 2015 the Government of Indonesia through the Directorate General of Waste, Hazardous and Toxic Material Management, Ministry of Environment and Forestry issued a Circular on Anticipatory Measures to Implement the Paid
Plastic Bag Policy in Modern Retail Businesses. This circular explains that one of the directions of government policy in the context of reducing waste, especially plastic bag waste is the application of paid plastic bag policies in all modern market outlets in Indonesia. The paid plastic bag policy is one strategy to reduce the rate of plastic bag waste generation which has been a pollutant for the environment $[17,18]$. Initially, it was hard, because it had to change people's habits, but to reduce the generation of plastic waste in the environment, the application of policies on reducing the use of disposable plastic bags needs to be encouraged $[19,20]$. This policy applies not only to modern retail stores but also in traditional markets.

\section{METHOD}

This study uses a quantitative method with a survey approach. The data in this study refer to the results of the field survey conducted in November 2019. The data is in the form of a data questionnaire and documentation. The study was conducted in a traditional market, namely Cemara Ujung Market, North Banjarmasin District. The choice of location was taken into consideration because this market was included in the area of the Banjarmasin City Government's policy trial plan related to the ban on the use of plastic bags. Administratively, Cemara Traditional Market is located in Jalan Cemara, Kelurahan Sungai Miai. The research targets were visitors (buyers) at Cemara Traditional Market, North Banjarmasin District who were the subject of the study because those who were directly affected were related to the plan to implement a policy prohibiting the use of plastic bags in traditional markets. The sampling technique was using accidental sampling, namely people who accidentally met with the researcher at the time of the survey and were used as respondents, if the person they met was appropriate as the data source. In total there are 55 respondents. The results of the questionnaire were elaborated based on frequency distribution, while for the measurement of WTP values the stated preference method was used. The WTP value of each respondent, which is in the form of the maximum value of rupiah that respondents are willing to pay for 1 plastic bag if they have to pay, is processed to get an average value (mean) from the PAP value.

\section{RESULT AND DISCUSSION 4.1 Consumer Perceptions of Government Policy on the Prohibition of the Use of Disposable Plastic Bags \\ 4.1.1 Characteristics of Respondents}

Most respondents were aged 17-24 years (36.66\%) and 4149 years $(18.18 \%)$. When viewed from the sex consists of $25,65 \%$ of men and $74.54 \%$ of women. The level of education of the respondents varied, with the highest being $54.55 \%$ high schools and $29.09 \%$ Bachelor/Postgraduate levels. While the types of occupations most respondents were Students were $32.73 \%$, Housewives $30.91 \%$, and Civil Servants $21.48 \%$. This illustrates the condition that respondents tend to have fairly high education, and are in the adult age range who are mostly students and 
housewives. The distribution of respondent characteristics based on these parameters is presented in Figure 1.
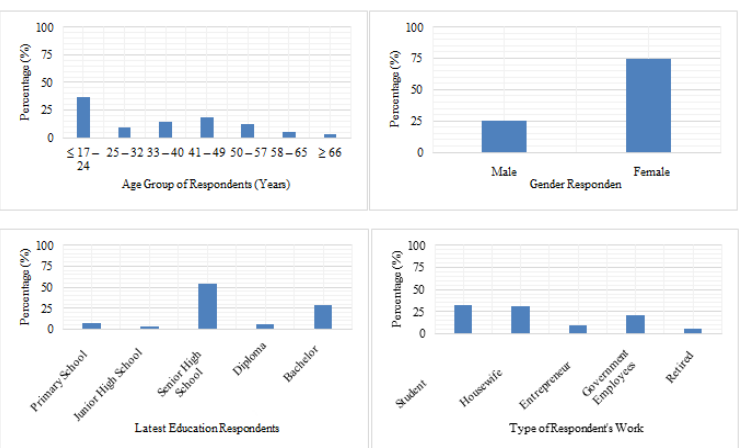

Figure 1 Distribution of Respondents Characteristics of Respondents

\subsubsection{Knowledge About Plastic Bags}

Plastic is an organic material that can be formed into various forms when exposed to heat and pressure. Its development, plastic is used in various forms and uses, such as tableware, food wrappers, optical lenses, building structures, furniture, fiberglass, and others. Especially for plastic bags themselves are usually made of Polyethylene (PE) [21], a thermoplastic material that can decompose in nature within 500-1000 years, so that it can damage the environment if scattered on the ground because it inhibits water infiltration, causes flooding, and damages fertility land [22, 23]. This requires public knowledge about plastic bags, their types, and their impact on the environment. Public knowledge about disposable plastic bags is presented in Table 1.

Table 1 Community Knowledge about Disposable Plastic Bags

\begin{tabular}{|c|c|c|c|c|}
\hline \multirow{2}{*}{ No } & \multirow{2}{*}{ Item Question } & \multicolumn{3}{|c|}{ Alternative Answer } \\
\hline & & $a$ & $b$ & $c$ \\
\hline 1 & What does $\mathrm{Mr} / \mathrm{Ms}$ know about plastic bags? & $\begin{array}{r}39 \\
(70.91 \%)\end{array}$ & $\begin{array}{r}9 \\
(16.36 \%)\end{array}$ & $\begin{array}{r}7 \\
(12.73 \%)\end{array}$ \\
\hline 2 & What types of plastic bags do you know? & $\begin{array}{r}23 \\
(41.82 \%)\end{array}$ & $\begin{array}{r}1 \\
(1.82 \%)\end{array}$ & $\begin{array}{r}31 \\
(56.36 \%)\end{array}$ \\
\hline 3 & According to you, what are the benefits of plastic bags? & $\begin{array}{r}45 \\
(81.82 \%) \\
\end{array}$ & $\begin{array}{r}8 \\
(14.55 \%)\end{array}$ & $\begin{array}{r}2 \\
(3.64 \%)\end{array}$ \\
\hline 4 & $\begin{array}{l}\text { What do you know about the advantages of plastic bags so that they are widely } \\
\text { used by the public? }\end{array}$ & $\begin{array}{r}42 \\
(76.36 \%)\end{array}$ & $\begin{array}{r}8 \\
(14.55 \%)\end{array}$ & $\begin{array}{r}5 \\
(9.09 \%) \\
-1\end{array}$ \\
\hline 5 & According to you, where are the harmful effects caused by plastic bags? & $\begin{array}{r}31 \\
(56.36 \%) \\
\end{array}$ & $\begin{array}{r}18 \\
(32.73 \%) \\
\end{array}$ & $\begin{array}{r}6 \\
(10.91 \%) \\
\end{array}$ \\
\hline 6 & What do you think about the use of plastic bags in everyday life? & $\begin{array}{r}40 \\
(72.73 \%) \\
\end{array}$ & $\begin{array}{r}11 \\
(20.00 \%) \\
\end{array}$ & $\begin{array}{r}4 \\
(7.27 \%) \\
\end{array}$ \\
\hline 7 & $\begin{array}{l}\text { Besides having an impact on the environment, do you know that the use of } \\
\text { plastic bags also has an impact on health, especially when covering food / hot } \\
\text { drinks? }\end{array}$ & $\begin{array}{r}30 \\
(54.55 \%)\end{array}$ & $\begin{array}{r}22 \\
(40.00 \%)\end{array}$ & $\begin{array}{r}3 \\
(5.45 \%)\end{array}$ \\
\hline 8 & $\begin{array}{l}\text { According to you, will the use of plastic bags every time shopping have an } \\
\text { impact on environmental pollution? }\end{array}$ & $\begin{array}{r}49 \\
(89.09 \%) \\
\end{array}$ & $\begin{array}{r}5 \\
(9.09 \%) \\
\end{array}$ & $\begin{array}{r}1 \\
(1.82 \%) \\
\end{array}$ \\
\hline
\end{tabular}

Most respondents generally knew about plastic bags, their benefits and uses, and their impact on the environment and health. As for knowledge about the types of plastic bags, of the 55 respondents, 31 respondents mentioned that the type of plastic bag was a plastic bag, 23 respondents mentioned recycled and non-recycled plastic, and only 1 respondent mentioned environmentally friendly plastic bags. The majority of respondents who mention the type of disposable plastic bags give reasons because this type of plastic bag is easy to find and has become a daily part of the community, especially used when shopping. At this time, many people have been introduced to the public types of plastic bags whose raw materials are environmentally friendly to replace disposable plastic bags (plastic bags) [24]. Quoting from the Technology Assessment and Application Agency (BPPT) page, there are three types of plastics with environmentally friendly raw materials. First, Deniable Grade Polyethylene (PE), this material will decompose after exposure to sunlight or pressure within one to two years. PE plastic can be used as shopping bags and other wrapping items. Second, plastic made from cassava starch (tapioca) is mixed with $\mathrm{PE}$, so that it breaks down naturally through a biological process with the principle of grafting. Third, plastic with starch and vegetable oil derivatives. The use of these natural ingredients can facilitate micro-organisms, organisms, and water in breaking down plastic $[25,26]$.

Public knowledge about the impact of the use of plastic bags for the environment, the majority of respondents know the impact, especially with the increasing pile of plastic waste that can pollute the environment because of the nature of the plastic that is difficult to decompose. Likewise with the impact on health, especially the use of plastic bags for wrapping food and drinks. If a plastic bag is exposed to heat from food/drinks, the chemicals contained in the plastic bag move/dissolve in food/drink [21,27]. Therefore, if forced to use plastic bags or tableware/drink made of plastic, use plastic materials that are safe for food/drink (food grade). 


\subsubsection{Knowledge of Respondents Regarding Banjarmasin Mayor Regulation About Reducing Use of Plastic Bags}

Banjarmasin City Mayor Regulation, published in 2016 on Reducing the Use of Plastic Bags, stated that reducing the use of plastic bags is a way to minimize volume, distribution, and use wisely and gradually reduce dependence on plastic bags, which are not environmentally friendly. This mayor's regulation came into force on June 1, 2016, and it is still in modern retail/markets such as minimarkets, supermarkets, and hypermarkets. Therefore, it needs to be applied in traditional markets, because traditional markets are the biggest contributor to plastic waste in the city of Banjarmasin. Table 2 presents community knowledge related to Banjarmasin City Mayor Regulation Number 18 the Year 2016 concerning Reducing the Use of Plastic Bags.

Table 2 Public Knowledge of Banjarmasin City Mayor Regulation Number 18 the Year 2016 concerning Reduction of Use of Plastic Bags

\begin{tabular}{|c|c|c|c|c|}
\hline \multirow{2}{*}{ No } & \multirow{2}{*}{ Item Question } & \multicolumn{3}{|c|}{ Alternative Answer } \\
\hline & & $a$ & $b$ & $c$ \\
\hline 10 & $\begin{array}{l}\text { What is your opinion/mother if the } \\
\text { reduction of plastic bag use that ev }\end{array}$ & $\begin{array}{r}48 \\
(87.27 \%) \\
\end{array}$ & $\begin{array}{r}5 \\
(9.09 \%) \\
\end{array}$ & $\begin{array}{r}2 \\
(3.64 \%) \\
\end{array}$ \\
\hline 11 & $\begin{array}{l}\text { Did you know about Banjarmasin Mayor Regulation No. } 18 \text { of } 2016 \\
\text { concerning Reducing the Use of Plastic Bags? }\end{array}$ & $\begin{array}{r}20 \\
(36.36 \%)\end{array}$ & $\begin{array}{r}23 \\
(41.82 \%)\end{array}$ & $\begin{array}{r}12 \\
(21.82 \%)\end{array}$ \\
\hline 12 & $\begin{array}{l}\text { The Banjarmasin Mayor Regulation has been implemented in modern } \\
\text { markets / retails (minimarkets/supermarkets/hypermarkets), for that, do you } \\
\text { agree if the regulation is also applied in traditional markets/markets? }\end{array}$ & $\begin{array}{r}38 \\
(69.09 \%)\end{array}$ & $\begin{array}{r}12 \\
(21.82 \%)\end{array}$ & $\begin{array}{r}5 \\
(9.09 \%)\end{array}$ \\
\hline
\end{tabular}

Respondents as many as 48 people $(87.27 \%)$ agreed if there were government policies related to reducing the use of plastic bags and even a ban on their use but, there were 5 people $(9.09 \%)$ and 2 people (3.64\%) whom each expressed less agree and disagree with the policy. According to those who agree, the existence of this policy can help change people's habits so that they can reduce the use of disposable plastic bags in everyday life, especially when shopping is lacking. Those who do not approve of the policy state that the plastic bags provided by traders have become part of their services, meaning that plastic bags have been provided by traders. The habits of the people using plastic bags when shopping are presented in Figure 2.habits of the people using plastic bags when shopping
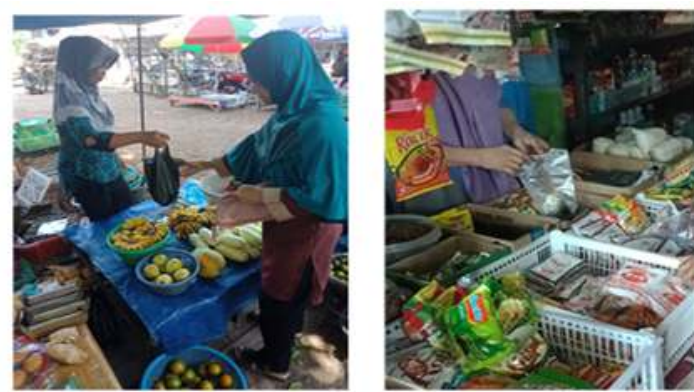

Figure 2 Community Habits Using Plastic Bags When Shopping (photo by Angriani, 2019)

Community's knowledge of Banjarmasin City Mayor Regulation 2016 concerning Reducing the Use of Plastic Bags, most respondents know about the regulations. 23 respondents $(41.82 \%)$ had heard/seen through reporting in the mass media, 20 respondents $(36.36 \%)$ knew clearly through government/mass media socialization, and only 12 respondents $(21.82 \%)$ did not know the regulation is due to limited information.

Respondents agreed that the Mayor Regulation on reducing the use of plastic bags was also applied in traditional markets. 38 respondents $(69.09 \%)$ stated their agreement, beginning with socialization to the community and implemented slowly, 12 respondents $(21.82 \%)$ still disagreed and 5 respondents said they did not agree if applied in traditional markets, because according to them will face many obstacles and require a long time in its implementation and can burden the community.

In principle, the community agrees and supports the policies of the Banjarmasin city government to overcome the problem of plastic bag waste, however, the community wants more socialization from the government regarding the implementation of the policy, so that the community gets sufficient information and is ready to participate in its implementation. The government together with environmental practitioners can provide knowledge related to alternative solutions to replace the use of plastic bags to more environmentally friendly materials.

\subsubsection{Respondents' Attitudes Regarding Reducing the Use of Plastic Bags}

Various methods are used to reduce the use of plastic bags in the community. Table 3 presents the attitudes/participation of respondents regarding their efforts to reduce the use of plastic bags, especially when shopping in traditional markets. 
Table 3 Public Attitudes Regarding Reducing the Use of Plastic Bags

\begin{tabular}{|c|c|c|c|c|}
\hline \multirow{2}{*}{ No } & \multirow{2}{*}{ Item Question } & \multicolumn{3}{|c|}{ Alternative Answer } \\
\hline & & $\mathbf{a}$ & b & c \\
\hline 9 & $\begin{array}{l}\text { According to } \mathrm{Mr} / \mathrm{Ms} \text {, what should be done to reduce plastic waste resulting } \\
\text { from the use of plastic bags in everyday life, especially when shopping at the } \\
\text { market? }\end{array}$ & $\begin{array}{r}40 \\
(72.73 \%)\end{array}$ & $\begin{array}{r}8 \\
(14.54 \%)\end{array}$ & $\begin{array}{r}7 \\
(12.73 \%)\end{array}$ \\
\hline 13 & $\begin{array}{l}\text { To reduce the use of plastic bags, if every shopping at the market and plastic } \\
\text { bags that come from traders are not free (for sale), do you agree? }\end{array}$ & $\begin{array}{r}40 \\
(72.73 \%)\end{array}$ & $\begin{array}{r}9 \\
(16.36 \%)\end{array}$ & $\begin{array}{r}6 \\
(10.91 \%)\end{array}$ \\
\hline 15 & $\begin{array}{l}\text { Do you agree if when shopping at the market, you bring your own plastic } \\
\text { bag/basket/shopping bag from home? }\end{array}$ & $\begin{array}{r}50 \\
(90.91 \%) \\
\end{array}$ & $\begin{array}{r}3 \\
(5.45 \%) \\
\end{array}$ & $\begin{array}{r}2 \\
(3.64 \%) \\
\end{array}$ \\
\hline
\end{tabular}

Based on Table 3 most respondents showed a positive attitude towards efforts to reduce the use of plastic bags. To reduce plastic waste due to the use of plastic bags in daily life, especially when shopping at the market, various ways they do it, including carrying their own shopping basket/bag (40 respondents $/ 72.73 \%$ ), reusing plastic bags that are still can be used ( 8 respondents / 14.54\%), and replace plastic bags with bags that are more environmentally friendly ( 7 respondents / $12.73 \%$ ).

To reduce the use of plastic bags, the majority of respondents (40 respondents / 72.73\%) agreed that every shopping at the market for shopping bags that came from traders was not free (sold separately). This, according to them, will slowly form public awareness and participate indirectly in protecting the environment. Although, there are still a small number of respondents ( 9 people / 16.36\% and 6 people / $10.91 \%$ ) who stated less and disagreed if the plastic bags of groceries wrapping are sold separately by traders because according to them they will inconvenience and burden the buyers and the supply of plastic bags has become part of the services of traders. Also, the reluctance of consumers to pay for plastic bags because there is an assumption that care for plastic waste should be a common concern and responsibility, not just be borne by consumers.
To reduce shipping costs due to paid plastic bags, respondents agreed to bring their own plastic bags/baskets/shopping bags from home (50 respondents / $90.91 \%$ ). While the rest stated that they did not agree with 3 respondents $(5.45 \%)$ and did not agree with 2 respondents (3.64\%). This is because it is bothersome and plastic bags should be provided by traders.

\subsection{Amount of Willingness To Pay of Plastic Bags If the Plastic Bag is Paid}

WTP is generally interpreted as the user's willingness to issue rewards (in money) for the services they receive. Relation to the environment, WTP, or willingness to pay is an individual's willingness to pay for an environmental condition or an assessment of natural resources and natural services to improve environmental quality [28] . WTP is calculated based on how far the ability of each individual or community in the aggregate to pay or spend money to improve environmental conditions to fit the desired conditions. The following is the value/price that respondents are able to pay for each plastic bag used when shopping at the market is presented in Table 4 .

Table 4 Value / Price That Consumers / Capable of Consumers Paying for Each Plastic Bag Used when Shopping at the Market

\begin{tabular}{|c|c|c|c|}
\hline No & Questions and Answers Alternative & $\begin{array}{l}\text { Frequency } \\
\text { (f) }\end{array}$ & $\begin{array}{l}\text { Percentage } \\
\quad(\%)\end{array}$ \\
\hline \multirow{4}{*}{14} & $\begin{array}{l}\text { If plastic bags are paying, what price range are capable of } \mathrm{Mr} / \mathrm{Mrs} \text { willing to pay } \\
\text { for each plastic bag used when shopping? }\end{array}$ & & \\
\hline & $\begin{array}{l}\text { a. Rp.1200 to Rp. } 1500 \text { for small/medium size plastic bags and Rp.1600 up to } \\
\text { Rp. } 2000 \text { for large plastic bags. }\end{array}$ & 3 & 5.88 \\
\hline & $\begin{array}{l}\text { b. Rp.500 to Rp. } 1000 \text { for small/medium size plastic bags and Rp.1200 to Rp. } 1500 \\
\text { for large size plastic bags. }\end{array}$ & 6 & 11.77 \\
\hline & $\begin{array}{l}\text { c. Rp. } 200 \text {, - up to Rp. } 500 \text {, - for small / medium size plastic bags and Rp. } 600,- \text { up } \\
\text { to Rp. } 1000 \text {, - for large size plastic bags. }\end{array}$ & 42 & 82.35 \\
\hline & Total & 51 & 100.00 \\
\hline
\end{tabular}

Based on Table 4, out of 55 respondents, 51 respondents were willing to pay for each plastic bag used when shopping, while 4 others stated that they did not agree to pay because plastic bags must be provided free by the merchant because it is part of the service. The magnitude of the availability of respondents (buyers) to pay for plastic bags when shopping at the market varies. The lowest value for each small/medium size plastic bag is Rp. 200, and the highest value is $\mathrm{Rp}$. 1500, - while the lowest value for a large size plastic bag is Rp. 600, and the highest is Rp. $2,000,-$. The calculation of the WTP value for each plastic bag is presented in Table 5 . 
Table 5 Value / Price that Capable / Capable for Consumers to Pay for Each Plastic Bag Used when Shopping in the Market

\begin{tabular}{|c|r|r|r|r|}
\hline No & Price Range (Rp) & $\begin{array}{c}\text { Average (Rp) } \\
(\mathbf{w})\end{array}$ & Number of Respondents (n) & $\begin{array}{c}\text { Total (wn) } \\
\text { (Rp) }\end{array}$ \\
\hline 1 & $200-500$ & 350 & & 42 \\
\hline 2 & $500-1,000$ & 750 & 6 & 14,700 \\
\hline 3 & $1,200-1,500$ & 1,350 & 3 & 4,500 \\
\hline \multicolumn{3}{|c|}{ total $(\Sigma)$} & 51 & 23,050 \\
\hline average & & & 32250 \\
\hline
\end{tabular}

Table 6 Calculation of Value WTP for Plastic Bag Size

\begin{tabular}{|c|r|r|r|r|}
\hline No. & Price Range (USD) & $\begin{array}{c}\text { Average (USD) } \\
\text { (d) }\end{array}$ & Number of Respondents (n) & \multicolumn{1}{c|}{ Total (wn) } \\
(RM)
\end{tabular}

Based on Table 5 and Table 6 it can be explained that for small/medium size plastic bags, the average value of the buyer's WTP is Rp.322.92 and Rp.654.17 for size plastic bags. This shows that the price of plastic bags that can be paid by buyers can still be reached so that buyers are still willing to pay more. A nominal amount of money is set to pay for the plastic bag, respondents expect environmental services in the form of improved environmental quality, which is free from the negative impact of plastic waste. The magnitude of the range of PAPs chosen by each respondent varies and depends on several factors, including gender, education level, age, monthly income, place to shop (in traditional markets or supermarkets), and average nominal spent on shopping at the market. This means that the level of the WTP value of the respondent depends on the level of these factors. So if you want to reduce the use of plastic bags in the community, the price of plastic bags must be even more expensive or look for alternatives to plastic bags, for example using shopping baskets/bags or using environmentally friendly plastic bags [24, 28].

\section{CONCLUSION}

Consumers are aware of government policies on reducing the use of plastic bags as stipulated in the Banjarmasin Mayor Regulation. They support if the policy is also applied in traditional markets because according to the disposable plastic bags if not used anymore will become garbage and hurt the environment and health. Also, the policy can increase public awareness and concern to reduce the use of plastic bags in everyday life. However, there are a few who stated less and disagreed regarding the policy plan. Various reasons were put forward, such as economic factors because it would add to the cost burden. To reduce plastic waste due to the use of plastic bags in everyday life, especially when shopping at the market, various ways can be done, including carrying baskets/shopping bags themselves, reusing plastic bags that can still be used, or using plastic bags that are more environmentally friendly. The average value of consumer WTP for one plastic bag varies both for small/medium size or for large size plastic and the price is still affordable by consumers because the price of paid plastic bags can still be reached by consumers, so they are still willing to pay more. So if you want to reduce the use of disposable plastic bags in the community, then the price of plastic bags must be even more expensive or look for alternatives to plastic bags, such as the use of baskets/shopping bags or the use of environmentally friendly plastic bags.

\section{ACKNOWLEDGMENT}

Thank you to the Faculty of Teacher Training and Education for supporting me to join an international conference. Thank you to my colleagues in the Geography Education Study Program for being a good colleague. Thank you to my parents who always support me.

\section{REFERENCES}

[1] K. Giesler, "The plastic problem: Plastic pollution in Bali," in Independent Study Project (ISP) Collection, S. G. Institute, Ed., ed. Indonesia: SIT Digital Collections, 2018, pp. 1-39.

[2] J. R. Jambeck, R. Geyer, C. Wilcox, T. R. Siegler, M. Perryman, A. Andrady, et al., "Plastic waste inputs from land into the ocean," Science, vol. 347, p. 768, 2015.

[3] S. Pereira, "Plastic perceptions: Surveying public opinion of plastic pollution in Rhode Island," Master of Arts, Marine Affairs, University of Rhode Island, 2019.

[4] S. Ekawati, "Mengkritisi kebijakan penanganan kantong plastik di Indonesia," Policy Brief, vol. 10, p. 4, 2016.

[5] P. Andarani, K. S. M. Puspandiyah, W. Budiawan, R. Purwaningsih, B. P. Samadikun, and A. Rezagama, "Preliminary study on plastic waste handling in Semarang City - Indonesia: Estimated generation and existing management," in ICENIS, Semarang, 2018. 
[6] P. Lestari and Y. Trihadiningrum, "The impact of improper solid waste management to plastic pollution in Indonesian coast and marine environment," Marine Pollution Bulletin, vol. 149, p. 110505, 2019/12/01/2019.

[7] P. Purwaningrum, "Upaya mengurangi timbulan sampah plastik di lingkungan," JTL, vol. 8, pp. 141-147, 2016.

[8] A. S. Suryani, "Persepsi masyarakat dan analisis willingness to pay terhadap kebijakan kantong plastik berbayar studi di jakarta dan bandung," Kajian, vol. 21, pp. 359-376, 2016.

[9] Helriansyah. (2019). Pasar tradisional penyumbang terbanyak sampah plastik di Tanahbumbu. Available: https://banjarmasin.tribunnews.com/2019/07/09/pa sar-tradisional-penyumbang-terbanyak-sampahplastik-di-tanahbumbu-ini-kata-kadis-lh

[10] J. Yulianus, "Banjarmasin perluas "diet plastik" ke pasar tradisional," in Harian Kompas, ed. Banjarmasin, 2019.

[11] N. A. Affandy, E. Isnaini, and C. H. Yulianti, "Peran serta masyarakat dalam pengelolaan sampah komprehensif menuju zero waste," in Seminar Nasional Sains dan Teknologi Terapan III 2015, Institut Teknologi Adhi Tama Surabaya, 2015, pp. 803-814.

[12] T. D. Nielsen, K. Holmberg, and J. Stripple, "Need a bag? A review of public policies on plastic carrier bags - Where, how and to what effect?," Waste Management, vol. 87, pp. 428-440, 2019/03/15/ 2019.

[13] T. P. Wagner, "Reducing single-use plastic shopping bags in the USA," Waste Management, vol. 70, pp. 3-12, 2017/12/01/ 2017.

[14] A. Macintosh, A. Simpson, T. Neeman, and K. Dickson, "Plastic bag bans: Lessons from the Australian Capital Territory," Resources, Conservation and Recycling, vol. 154, p. 104638, 2020/03/01/2020

[15] G. O. Thomas, E. Sautkina, W. Poortinga, E. Wolstenholme, and L. Whitmarsh, "The English Plastic Bag Charge Changed Behavior and Increased Support for Other Charges to Reduce Plastic Waste," Frontiers in Psychology, vol. 10, 2019-February-26 2019.

[16] mnlh.go.id. (2015, 25/10). Dialog penanganan sampah plastik. Available: www.menlh.go.id/rangkaian-hlh-2015-dialogpenanganan-sampah-plastik/

[17] D. Knoblauch, L. Mederake, and U. Stein, "Developing Countries in the Lead-What Drives the Diffusion of Plastic Bag Policies?," Sustainability, vol. 1994, 06/14 2018.
[18] M. W. Kwori, "South Sudans ban of plastic carrier bags: An empirical move or an emulation?," City and Environment Interactions, p. 100019, 2019/12/19/2019.

[19] L. M. Heidbreder, I. Bablok, S. Drews, and C. Menzel, "Tackling the plastic problem: A review on perceptions, behaviors, and interventions," Science of The Total Environment, vol. 668, pp. 1077-1093, 2019/06/10/2019.

[20] G. Martinho, N. Balaia, and A. Pires, "The Portuguese plastic carrier bag tax: The effects on consumers' behavior," Waste Management, vol. 61, pp. 3-12, 2017/03/01/ 2017.

[21] E. Hansen, N. H. Nilsson, D. Lithner, and C. Lassen, "Hazardous substances in plastic materials," Danish Technological Institute, Vejle, Denmark2013.

[22] S. J. Barnes, "Understanding plastics pollution: The role of economic development and technological research," Environmental Pollution, vol. 249, pp. 812-821, 2019/06/01/ 2019.

[23] S. J. Barnes, "Out of sight, out of mind: Plastic waste exports, psychological distance and consumer plastic purchasing," Global Environmental Change, vol. 58, p. 101943, 2019/09/01/ 2019.

[24] A. Harianja, G. Saragih, and R. Fauzi, "Replacing single use plastic bags with compostable carriers: socio-economic approach," IOP Conference Series: Earth and Environmental Science, vol. 407, p. 012001, 12/17 2019.

[25] bppt.go.id. (2010). Plastik ramah lingkungan: Untuk bumi yang lebih hijau. Available: https://www.bppt.go.id/teknologi-sumberdayaalam-dan-kebencanaan/641-plastik-ramahlingkungan-untuk-bumi-yang-lebih-hijau

[26] cnnindonesia.com. (2019, 25/10/2019). Menilik 3 plastik kresek ramah lingkungan. Available: https://www.cnnindonesia.com/teknologi/2019073 1182305-199-417173/menilik-3-plastik-kresekramah-lingkungan

[27] K. J. Groh, T. Backhaus, B. Carney-Almroth, B. Geueke, P. A. Inostroza, A. Lennquist, et al., "Overview of known plastic packaging-associated chemicals and their hazards," Science of The Total Environment, vol. 651, pp. 3253-3268, 2019/02/15/ 2019.

[28] P. K. Madigele, G. E. J. Mogomotsi, and M. Kolobe, "Consumer willingness to pay for plastic bags levy and willingness to accept eco-friendly alternatives in Botswana," Chinese Journal of Population Resources and Environment, vol. 15, pp. 255-261, 2017/07/03 2017. 